\title{
Genetic Polymorphism of $\beta$-Casein Gene in Polish Red Cattle-Preliminary Study of A1 and A2 Frequency in Genetic Conservation Herd
}

\author{
Anna Cieślińska *(D), Ewa Fiedorowicz, Grzegorz Zwierzchowski®, Natalia Kordulewska®D, \\ Beata Jarmołowska and Elżbieta Kostyra \\ Department of Biochemistry, Faculty of Biology and Biotechnology, University of Warmia and Mazury in \\ Olsztyn, Oczapowskiego 1A, 10-719 Olsztyn, Poland; ewa.kuzbida@uwm.edu.pl (E.F.); \\ grzegorz.zwierzchowski@uwm.edu.pl (G.Z.); natalia.smulska@uwm.edu.pl (N.K.); bj58@wp.pl (B.J.); \\ elzbieta.kostyra@uwm.edu.pl (E.K.) \\ * Correspondence: anna.cieslinska@uwm.edu.pl; Tel.: +48-89-523-37-63
}

Received: 2 May 2019; Accepted: 18 June 2019; Published: 20 June 2019

Simple Summary: Currently, milk and dairy products are considered nutritious foods because they contain bioactive constituents. However, in some cases, milk consumption might cause health-related issues, such as allergic reactions. Among all of the proteins present in milk, caseins deserve special attention. A genetic variant called $\beta$-casein is recognized as a potential cause of some health implications. However, although milk protein characteristics have been widely covered, a significant majority of published research focus on one cattle breed: Holstein There are numerous local breeds that have not been widely analyzed to date. One such breed is a dual-purpose breed called Polish Red.

\begin{abstract}
Although there is growing interest in Red cow's milk in Poland, to date there are few reports investigating the characteristics of milk components in the studied population. Particular emphasis on milk proteins is advised, since $\beta$-casein is a source of bioactive peptides named $\beta$-casomorphins. $\beta$-casomorphin 7 , which originates mostly from $\beta$-casein variants $A 1$, may be a significant risk factor in human ischemic heart disease, arteriosclerosis, type I diabetes, sudden infant death syndrome, and autism. The aim of the present study was to identify CSN2 polymorphism gene in exon 7 using the genomic sequence from GenBank (M55158), g.8101C >A, (codon 67). Blood samples were collected from 201 Polish Red cattle (24 males and 177 females). The genotype of $\beta$-casein was determined using PCR-ACRS. The frequency of $\beta$-casein A2 in Polish Red population was 0.47 . $\beta$-casein A2 frequency in Polish Red bulls and in cows was 0.58 and 0.37 , respectively.
\end{abstract}

Keywords: genetic variation; proteins; milk quality; milk casein; cows

\section{Introduction}

The Polish Red (PR) breed population is increasing in numbers, although the most numerous dairy breed in Poland is Polish Holstein-Friesian (PHF). However, an increasing number of farmers are becoming more interested in the PR breed due to its high resistance and perfect adaptation to harsh environmental conditions. Moreover, PR is valued for its health, longevity, good fertility, and the high biological value of its milk. Due to the aforementioned benefits, PR was entered into the Genetic Resources Conservation Program, whose purpose is to preserve the genetic resources and diversity of native breeds and protect their gene pools [1]. Despite the fact that in Poland the PR is the breed mostly used as the meat type, the milk type head number is increasing in the overall PR population. Importantly, consumers are becoming more interested in PR milk due to its potential health benefits, 
which is encouraging a wider investigation of the characteristics of the milk produced from the studied population.

Proteins are one of the most important milk components, out of which caseins have received the greatest attention due to their recognized health-related properties. One of the major milk proteins is $\beta$-casein, and one of four casein milk proteins is particularly interesting. $\beta$-casein has 209 amino acid residues in its protein chain, and its gene (CSN2) belongs to the cluster of four casein genes located on chromosome 6 [2,3]. The most frequent genetic variants of CSN2 are A1 and A2 [4,5]. The mutation that causes differences in the $\beta$-casein protein is a result of a single nucleotide polymorphism at codon 67 in exon 7 of the gene CCT (A2, proline) which results in CAT (A1, histidine) [2]. Bioactive peptide $\beta$-casomorphin 7 [5,6], which originates mostly from $\beta$-casein variants A1 [7-9], may be a significant risk factor in human ischemic heart disease, arteriosclerosis, type I diabetes, sudden infant death syndrome, and autism [5,10-13].

To our best knowledge, research has not yet been conducted on the frequency of bovine $\beta$-casein variants in PR. Therefore, we decided to analyze the frequency of the A1 and A2 allele of the $\beta$-casein gene in PR. In the presented work, our main aim was to identify CSN2 polymorphism (GenBank M55158; g.8101C >A) gene within the exon 7 sequence. The experiment was conducted in a PR herd located in the north-east region of Poland.

\section{Materials and Methods}

\section{DNA Isolation and Genotyping}

Blood samples were collected from 201 dual-purpose PR ( 24 bulls and 177 cows; born from 2001 to 2017) belonging to a herd located in the north-east region of Poland. All samples were collected by a veterinarian from the jugular vein. DNA was isolated from $200 \mu \mathrm{l}$ of whole blood using GeneJET Whole Blood Genomic DNA Purification Mini Kit (Thermo Scientific, Waltham, MA, USA) according to the manufacturer's instructions. The genotypes of $\beta$-casein locus (GenBank sequence acc. no. M55158)—A2 allele (CCT, GenBank: JX273429.1) and A1 allele (CAT, GenBank: JX273430.1) was determined using the PCR-ACRS (Amplification Created Restriction Site) described by Oleński et al. [14] with modifications. The contents in the $25-\mu \mathrm{L}$ mixture consisted of DreamTaq Green Master Mix (Thermo Scientific), $150 \mathrm{ng}$ of DNA, and molecularly pure water (Sigma-Aldrich, St. Louis, MO, USA), and starters with the following sequences:

\section{CASB forward: 5'-GCAGAATTCTAGTCTATCCCTTCCCTGGACCCATGC-3' CASB reverse: 5'-ACGGACTGAGGAGGAAACATGACAGTTGGAGGAAG-3'}

PCR amplification was conducted in a thermal cycler according to the following program: initial denaturation: $94{ }^{\circ} \mathrm{C}$ for $3 \mathrm{~min}$, proper denaturation: $94{ }^{\circ} \mathrm{C}$ for $30 \mathrm{~s}$, attaching the starters at $62^{\circ} \mathrm{C}$ for $30 \mathrm{~s}$, synthesis: $72{ }^{\circ} \mathrm{C}$ for $30 \mathrm{~s}$, final synthesis: $72{ }^{\circ} \mathrm{C}$ for $5 \mathrm{~min}$, number of cycles: 40 , cooling: $4{ }^{\circ} \mathrm{C}$. The yield and specificity of the PCR products were evaluated after electrophoresis in $1.5 \%$ agarose gel (Promega, Madison, WI, USA) with GelGreen Nucleic Acid Gel Stain (Biotium, Fremont, CA, USA). To determine the genotype, restriction enzyme Mph1103I (NsiI, Thermo Scientific) was used and then electrophoresed in 2.5\% agarose gel (Promega) with GelGreen Nucleic Acid Gel Stain (Biotium). Each A2A2 homozygote was confirmed a second time via a genotyping procedure. Genetic equilibrium of the examined population was estimated due to the Hardy-Weinberg principle and tested with the chi-square test (www.dr-petrek.eu/documents/HWE.xls). The study was conducted with compliance to local bioethics committee guidelines (18/2013).

\section{Results and Discussion}

The observed genotype frequencies of A1/A2 $\beta$-casein polymorphism conformed to the Hardy-Weinberg equilibrium. The frequency of $\beta$-casein A2 allele in the entire research Polish Red population was 0.47 , which, according to a comparison of the frequencies of the CSN2 allele in 
Red breeds in other European countries, was similar to the frequency observed in the Swedish PR population-0.51 [15]. The frequencies of the $\beta$-casein A1 and A2 alleles and genotypes in the research population are presented in Table 1 . The obtained $\beta$-casein A2 frequency in research PR population was lower than the frequency observed in the Holstein-Friesian breed in Poland-0.6-0.65 [5,14,16], and in other European countries (Table 2). In PR cows, the A2-allele frequency was 0.37, and in bulls it was 0.58 . The high frequency of the $\beta$-casein A2 allele in the tested bulls may be an effect of the small number of tested animals. However, it should be noted that bulls as donors of semen are the main source of the genetic pool.

Table 1. Genotype and allele frequency of $\beta$-casein in Polish Red cows and bulls.

\begin{tabular}{ccccccc}
\hline \multirow{2}{*}{ Group } & \multicolumn{2}{c}{$\boldsymbol{N}(\%)$ of $\boldsymbol{\beta}$-Casein Genotypes } & \multicolumn{2}{c}{ Frequency of Alleles } & \multirow{2}{*}{$\boldsymbol{p}$-Value } \\
\cline { 2 - 6 } & $\mathbf{A 1 A 1}$ & $\mathbf{A 1 A 2}$ & $\mathbf{A 2 A 2}$ & $\mathbf{A 1}$ & $\mathbf{A 2}$ & \\
\hline Cows & $65(36.7)$ & $93(52.5)$ & $19(10.7)$ & 0.63 & 0.37 & 0.001 \\
Bulls & $3(12.5)$ & $14(58.3)$ & $7(29.2)$ & 0.42 & 0.58 & 0.001 \\
\hline
\end{tabular}

Our results present the distribution of CSN2 A2 and A1 alleles among PR cows and bulls in an analyzed herd from the north-east region of Poland. Because PR milk is characterized as having greater protein content, and consequently $\beta$ - and $\kappa$-casein percentage [17], it might be considered as a relevant source of nutritional components for humans. On the contrary, the adverse effect of the $\beta$-casein A1 variant on human health has been widely discussed [18-20]. Moreover, New Zealand was the first country to have eliminated the A1 allele from its dairy cattle population, with no negative effect on milk yield and composition [5].

Table 2. Occurrence of $\beta$-casein gene variants in Holstein-Friesian (HF) in Poland and Red in other countries (data sorted by increasing A1 allele frequency) (adapted from Kamiński et al., 2007 [5]).

\begin{tabular}{|c|c|c|c|c|c|}
\hline \multirow[t]{2}{*}{ Breed } & \multirow[t]{2}{*}{ Country } & \multicolumn{2}{|c|}{$\begin{array}{c}\text { Allele Frequency } \\
\text { of } \beta \text {-Casein }\end{array}$} & \multirow[t]{2}{*}{$N$} & \multirow[t]{2}{*}{ References } \\
\hline & & A1 & A2 & & \\
\hline \multirow{12}{*}{$\mathrm{HF}$} & Denmark & 0.266 & 0.614 & 415 & Gustavsson et al., 2014 [15] \\
\hline & The Netherlands & 0.28 & 0.50 & 1929 & Visker et al., 2010 [21] \\
\hline & The Netherlands & 0.029 & 0.69 & 1629 & Heck et al., 2009 [22] \\
\hline & Poland & 0.32 & 0.68 & 177 & Cieślińska et al., 2012 [8] \\
\hline & Poland & 0.35 & 0.65 & 650 & Oleński et al., 2012 [14] \\
\hline & Thailand & 0.363 & 0.602 & 231 & Molee et al., 2011 [23] \\
\hline & Italy & 0.371 & 0.546 & 1226 & Massella et al., 2017 [24] \\
\hline & Italy & 0.395 & 0.57 & 100 & Chessa et al., 2013 [25] \\
\hline & Poland & 0.40 & 0.60 & 143 & Kamiński et al., 2006 [16] \\
\hline & China & 0.432 & 0.459 & 133 & Dai et al., 2016 [26] \\
\hline & Turkey & 0.485 & 0.456 & 49 & Dinc et al., 2013 [27] \\
\hline & Iran & 0.50 & 0.50 & 119 & Gholami et al., 2016 [28] \\
\hline \multirow{3}{*}{ Red } & Sweden & 0.48 & 0.51 & 392 & Gustavsson et al., 2014 [15] \\
\hline & Denmark & 0.71 & 0.23 & 169 & $\begin{array}{c}\text { Bech and Kristiansen, } 1990 \\
\text { [29] }\end{array}$ \\
\hline & Poland & 0.53 & 0.47 & 201 & Present data \\
\hline
\end{tabular}

Other variants of the $\beta$-casein gene are not included.

DNA-based genotyping is a fast and low-cost method. It allows for the $\beta$-casein A1 frequency to be monitored in dairy cattle in order to avoid the spread of an unfavorable allele in a population of cattle. Although a relatively high frequency of $\beta$-casein A1 allele was observed in PR cattle, it is important to note that a high turnout of the desired allele is observed in the bull population. Information on $\beta$-casein genotypes will allow for more conscious crossbreeding of animals and the elimination of an unfavorable allele from the population. 


\section{Conclusions}

As the A2 beta-casein variant in milk is desirable in the population of cattle, the Polish Red breed, which is undergoing the reconstruction of the herd, provides a good potential for increasing this favorable allele through appropriate breeding of individuals. Moreover, the high turnout of the A2 beta-casein allele (0.58) among the red Polish bulls may increase its attendance among the entire population.

Author Contributions: Conceptualization: A.C. and E.F.; methodology: A.C. and E.F.; formal analysis: G.Z. and E.F.; investigation: A.C. and E.F.; resources: N.K. and B.J.; writing-original draft preparation: A.C., E.F., and G.Z.; writing-review and editing: A.C., G.Z., and E.K.; supervision: A.C. and E.K.; project administration: A.C. and B.J.

Acknowledgments: The authors are grateful to Piotr Rydel, Agnieszka Prochal, and Roman Wójcik, for their support.

Conflicts of Interest: The funders had no role in the design of the study; in the collection, analyses, or interpretation of data; in the writing of the manuscript, or in the decision to publish the results.

\section{References}

1. Krupiński, J. Ochrona zasobów genetycznych zwierząt gospodarskich w Polsce. Wiadomości Zootech. 2008, 1, 1-10.

2. Farrel, H.M. Casein Nomenclature, Structure, and Association. In Encyclopedia of Dairy Sciences; Roginsky, H., Fuquay, J., Fox, P., Eds.; Academic Press: London, UK, 2003.

3. Truswell, A.S. The A2 milk case: A critical review. Eur. J. Clin. Nutr. 2005, 59, 623. [CrossRef] [PubMed]

4. Farrell, H.M.; Jimenez-Flores, R.; Bleck, G.T.; Brown, E.M.; Butler, J.E.; Creamer, L.K.; Swaisgood, H.E. Nomenclature of the proteins of cows' milk-Sixth revision. J. Dairy Sci. 2004, 87, 1641-1674. [CrossRef]

5. Kamiński, S.; Cieślińska, A.; Kostyra, E. Polymorphism of bovine beta-casein and its potential effect on human health. J. Appl. Genet. 2007, 48, 189-198. [CrossRef] [PubMed]

6. Jarmołowska, B.; Kostyra, E.; Krawczuk, S.; Kostyra, H. $\beta$-Casomorphin-7 isolated from Brie cheese. J. Sci. Food Agric. 1999, 79, 1788-1792. [CrossRef]

7. Kostyra, E.; Sienkiewicz-Szłapka, E.; Jarmołowska, B.; Krawczuk, S.; Kostyra, H. Opioid peptides derived from milk proteins. Pol. J. Food Nutr. Sci. 2004, 13/54, $25-35$.

8. Cieślińska, A.; Kostyra, E.; Kostyra, H.; Oleński, K.; Fiedorowicz, E.; Kamiński, S. Milk from cows of different $\beta$-casein genotypes as a source of $\beta$-casomorphin-7. Int. J. Food Sci. Nutr. 2012, 63, 426-430. [CrossRef] [PubMed]

9. Jinsmaa, Y.; Yoshikawa, M. Enzymatic release of neocasomorphin and beta-casomorphin from bovine beta-casein. Peptides 1999, 20, 957-962. [CrossRef]

10. Cieślińska, A.; Sienkiewicz-Szłapka, E.; Wasilewska, J.; Fiedorowicz, E.; Chwała, B.; Moszyńska-Dumara, M.; Kostyra, E. Influence of candidate polymorphisms on the dipeptidyl peptidase IV and $\mu$-opioid receptor genes expression in aspect of the $\beta$-casomorphin-7 modulation functions in autism. Peptides 2015, 65, 6-11. [CrossRef]

11. Kost, N.V.; Sokolov, O.Y.; Kurasova, O.B.; Dmitriev, A.D.; Tarakanova, J.N.; Gabaeva, M.V.; Mikheeva, I.G. $\beta$-Casomorphins-7 in infants on different type of feeding and different levels of psychomotor development. Peptides 2009, 30, 1854-1860. [CrossRef]

12. Petrat-Melin, B.; Andersen, P.; Rasmussen, J.T.; Poulsen, N.A.; Larsen, L.B.; Young, J.F. In vitro digestion of purified $\beta$-casein variants $\mathrm{A}(1), \mathrm{A}(2), \mathrm{B}$, and I: Effects on antioxidant and angiotensin-converting enzyme inhibitory capacity. J. Dairy Sci. 2015, 98, 15-26. [CrossRef] [PubMed]

13. Reichelt, K.L.; Tveiten Bioengineer, D.; Knivsberg, A.M.; Brønstad, G. Peptides' role in autism with emphasis on exorphins. Microb. Ecol. Health D 2012, 23, 18958. [CrossRef] [PubMed]

14. Oleński, K.; Cieślińska, A.; Suchocki, T.; Szyda, J.; Kamiński, S. Polymorphism in coding and regulatory sequences of beta-casein gene is associated with milk production traits in Holstein-Friesian cattle. Anim. Sci. Pap. Rep. 2012, 30, 12.

15. Gustavsson, F.; Buitenhuis, A.J.; Johansson, M.; Bertelsen, H.P.; Glantz, M.; Poulsen, N.A.; Paulsson, M. Effects of breed and casein genetic variants on protein profile in milk from Swedish Red, Danish Holstein, and Danish Jersey cows. J. Dairy Sci. 2014, 97, 3866-3877. [CrossRef] [PubMed] 
16. Kamiński, S.; Ruść, A.; Cieślińska, A. A note on frequency of A1 and A2 variants of bovine beta casein locus in Polish Holstein bulls. J. Anim. Feed Sci. 2006, 15, 195-198. [CrossRef]

17. Grega, T.; Sady, M.; Najgebauer, D.; Domagala, J.; Faber, B. Bioactive components of milk from different cow breeds. Biotechnol. Anim. Husb. 2005, 21,35-38. [CrossRef]

18. Clemens, R.A. Milk A1 and A2 peptides and diabetes. In Milk and Milk Products in Human Nutrition; Clemens, R.A., Hernell, O., Michaelsen, K.F., Eds.; Nestec Ltd.: Vevey, Switzerland; S. Karger AG: Basel, Switzerland, 2011; Volume 67, pp. 187-195.

19. European Food Safety Authority. Review of the potential health impact of $\beta$-casomorphins and related peptides. EFSA Sci. Rep. 2009, 231, 1-107.

20. Swinburne, B. Beta Casein A1 and A2 in Milk and Human Health. Report to New Zealand Food Safety Authority; 2004. Available online: https://www.foodsafety.govt.nz/elibrary/industry/Beta_Casein-Report_ Reviews.pdf (accessed on 20 June 2019).

21. Visker, M.H.P.W.; Dibbits, B.W.; Kinders, S.M.; Van Valenberg, H.J.F.; Van Arendonk, J.A.M.; Bovenhuis, H. Association of bovine $\beta$-casein protein variant I with milk production and milk protein composition. Anim. Genet. 2011, 42, 212-218. [CrossRef] [PubMed]

22. Heck, J.M.L.; Schennink, A.; Van Valenberg, H.J.F.; Bovenhuis, H.; Visker, M.H.P.W.; Van Arendonk, J.A.M.; Van Hooijdonk, A.C.M. Effects of milk protein variants on the protein composition of bovine milk. J. Dairy Sci. 2009, 92, 1192-1202. [CrossRef] [PubMed]

23. Molee, A.; Boonek, L.; Rungsakinnin, N. The effect of beta and kappa casein genes on milk yield and milk composition in different percentages of Holstein in crossbred dairy cattle. Anim. Sci. J. 2011, 82, 512-516. [CrossRef]

24. Massella, E.; Piva, S.; Giacometti, F.; Liuzzo, G.; Zambrini, A.V.; Serraino, A. Evaluation of bovine beta casein polymorphism in two dairy farms located in northern Italy. Ital. J. Food Saf. 2017, 6, 6904. [CrossRef] [PubMed]

25. Chessa, S.; Bulgari, O.; Rossoni, A.; Ceriotti, G.; Caroli, A.M. Bovine $\beta$-casein: Detection of two single nucleotide polymorphisms by bidirectional allele specific polymerase chain reaction (BAS-PCR) and monitoring of their variation. OJAS 2013, 3, 36. [CrossRef]

26. Dai, R.; Fang, Y.; Zhao, W.; Liu, S.; Ding, J.; Xu, K.; Meng, H. Identification of alleles and genotypes of beta-casein with DNA sequencing analysis in Chinese Holstein cow. J. Dairy Res. 2011, 83, 312-316. [CrossRef] [PubMed]

27. Dinc, H.; Ozkan, E.; Koban, E.; Togan, I. Beta-casein A1/A2, kappa-casein and beta-lactoglobulin polymorphisms in Turkish cattle breeds. Arch. Anim. Breed. 2013, 56, 650-657. [CrossRef]

28. Gholami, M.; Hafezian, S.; Rahimi, G.; Farhadi, A.; Rahimi, Z.; Kahrizi, D.; Veisi, F. Allele specific-PCR and melting curve analysis showed relatively high frequency of $\beta$-casein gene A1 allele in Iranian Holstein, Simmental and native cows. Cell. Mol. Biol. 2016, 62, 138-143.

29. Bech, A.M.; Kristiansen, K.R. Milk protein polymorphism in Danish dairy cattle and the influence of genetic variants on milk yield. J. Dairy Res. 1990, 57, 53-62. [CrossRef] [PubMed]

(C) 2019 by the authors. Licensee MDPI, Basel, Switzerland. This article is an open access article distributed under the terms and conditions of the Creative Commons Attribution (CC BY) license (http://creativecommons.org/licenses/by/4.0/). 